\title{
Ultrasound and excretory urography findings in the diagnostic of congenital renal ectopy of a dog
}

\author{
Achados de ultrassonografia e urografia excretora no \\ diagnóstico de ectopia renal congênita em um cão
}

\author{
Letícia Maria de Almeida Santos ${ }^{1 *}\left(\mathbb{D}\right.$, Taysa Trindade ${ }^{1}\left(\mathbb{D}\right.$, Luiza Bordignon ${ }^{1}\left(\mathbb{D}\right.$, Ana Letícia Kaiser ${ }^{1}$ (1), \\ Jaqueline Lunedo ${ }^{2}$ (D), Flávio Shigueru Jojima ${ }^{3}$ (D)
}

\begin{abstract}
Renal ectopy is a rare condition in small animals, characterized by abnormal positioning of one or both kidneys. It is classified as simple or crossed and, according to its localization, being diagnosed in an incidental way in pets because of its nonspecific and many times asymptomatic clinical presentation. Imaging exams such as ultrasound, radiography, and excretory urography may close the diagnosis. This paper reports a case of simple, unilateral, renal ectopy, in a three-year-old male Lhasa Apso dog, with no clinical or laboratory findings consistent with renal disease, in which the ectopic condition, together with shape, rotation, and vascular abnormalities, were incidental findings during abdominal ultrasound examination.
\end{abstract}

KEYWORDS: Ectopic. Kidney. Ultrasound. Excretory Urography.

RESUMO: A ectopia renal é uma condição rara em pequenos animais, caracterizada pelo posicionamento anormal de um ou ambos os rins. É classificada como simples ou cruzada e de acordo com a sua localização, sendo diagnosticada de forma incidental nos animais de companhia em decorrência de sua apresentação clínica inespecífica e muitas vezes assintomática. Os exames de imagem como ultrassonografia, radiografia e urografia excretora podem fechar o diagnóstico. Esse trabalho relata um caso de ectopia renal simples e unilateral em um cáo macho da raça Lhasa Apso de três anos de idade, sem apresentaçóes clínicas e laboratoriais condizentes de doença renal, no qual o rim ectópico associado a anomalias de forma, rotação e vasculares foram achados incidentais durante o exame ultrassonográfico abdominal.

PALAVRAS-CHAVE: Ectópico. Rim. Ultrassonografia. Urografia Excretora.

\section{INTRODUCTION}

Congenital renal diseases are frequent causes of renal failure in dogs, presenting a hereditary trait or racial predisposition (LEES, 1996). Renal ectopy, which consists of the abnormal positioning of one or both kidneys, is a congenital anomaly related to development that has already been diagnosed in dogs, cats, and calves (CHARAN, 1997; ALLWORTH and HOFFMAN, 1999; GRECO, 2001; CHOI et al., 2012).

In Medicine, renal ectopy is classified as simple, in which the kidney is on its original site but in an intrathoracic, abdominal, iliac, or pelvic position; or crossed, when one of the kidneys remains contralateral to the insertion of its ureter in the urinary bladder (BARBARIC, 1994; FOTTER,
2008; KIM, 2012). When the kidneys are interconnected forming a single mass, this condition is called fused renal ectopy (SOLANKI et al., 2013).

Usually asymptomatic, simple renal ectopy is a condition rarely described in small animals, being diagnosed incidentally due to its nonspecific clinical presentation (BRUCKNER et al., 2010). It is believed that its etiology is related to failure in the growth or development of the ureteric bud or metanephric mesenchyme, due to injury of the renal tissue during the embryonic development, resulting in mechanical resistance created by the attached structures that prevent the normal ascension of the kidneys (ALLWORTH and HOFFMAN, 1999). 
The diagnosis can be confirmed by ultrasound, radiography, and excretory urography. Image findings may include abnormal kidney location, altered shape, reduced size, organ rotation, decreased ureteral length, and abnormal renal vascularization (JOHNSON, 1979; NYLAND and MATTOON, 2005). However, the use of computerized tomography and magnetic resonance imaging can bring more information about the diagnosis and treatment of this condition (CAOILI et al., 2002).

Although most ectopic kidneys have their function preserved, the lower position of the kidney associated with a short ureter, anomalous vascularization, and defects in the collecting system predispose this organ to reflux, infections, and lithiasis. In addition, malposition of the ureters can lead to urinary flow obstruction, resulting in pielectasis, followed by hydronephrosis (KUMAR, 2005; FOTTER, 2008; NEWMAN et al., 2013).

This paper aims to report a case of congenital unilateral simple renal ectopy in a three-year-old dog, diagnosed by abdominal ultrasound and excretory urography, focusing on the image findings.

\section{CASE REPORT}

A three-year-old male Lhasa Apso canine patient presenting abdominal pain with a history of recurrent cystitis was admitted at a Veterinary School Hospital. In the physical evaluation, all parameters were within normality for the species, being only responsive to pain on palpation in the caudal abdomen region. There, it was possible to palpate a massive structure with smooth contours, bringing the suspicion of abdominal neoformation. Hematological and biochemical tests were within the reference parameters for the species.

Considering the clinical suspicion, an ultrasound was requested and the changes observed were the thickening and irregularity of the bladder wall, with the presence of a moderate amount of urinary sediment/cellular debris, suggesting the presence of an inflammatory/infectious process (cystitis). In addition, the left kidney was out of its habitual topography, being located in the caudomedial abdomen, cranially to the urinary bladder, with a subtle bulging at the medial margin of the cranial pole, changing its shape (Figure 1). Echogenic points indicative of mineralization in bilateral renal cortical and medullary parenchyma have also been described, with the only ultrasound alterations being observed in the right kidney.

The color Duplex Doppler of the left kidney showed a cranioventrally projected renal hilum, suggesting a physiological non-rotation of this organ during the fetal development. Further, a pulsating vessel emerged from the interlobar arteries and extended caudally until it merged with a large caliber artery in the region (Figure 2).

After the ultrasound findings, the excretory urography was recommended to complement the diagnosis of renal ectopy and to detect possible associated ureteral anomalies. First, plain radiographs of the abdominal region in right/left, lateral, and ventrodorsal views were taken. Then, $8 \mathrm{ml}$ of iodinated contrast agent was intravenously administered, and new radiographic images were obtained at 7s, $5 \mathrm{~min}, 15 \mathrm{~min}, 30 \mathrm{~min}$, and $2 \mathrm{~h}$ after total injection.

The corresponding images obtained at five minutes after the administration of the contrast medium administration showed the filled right and left renal pelvis, besides the ureters, and bladder. The left kidney was individualized ventrally to the L5 and L6 vertebrae with a more rounded shape and the corresponding proximal ureter projected cranially, besides the decreased length compared to the right ureter (Figure 3), confirming the positional and rotational anomaly observed at the ultrasound.

The ectopy of the left kidney was confirmed by the radiographic and ultrasound findings, being classified as simple, unilateral, and congenital, with the associated shape and rotation anomalies, besides the anomalous vascularization and reduced ureteral length.

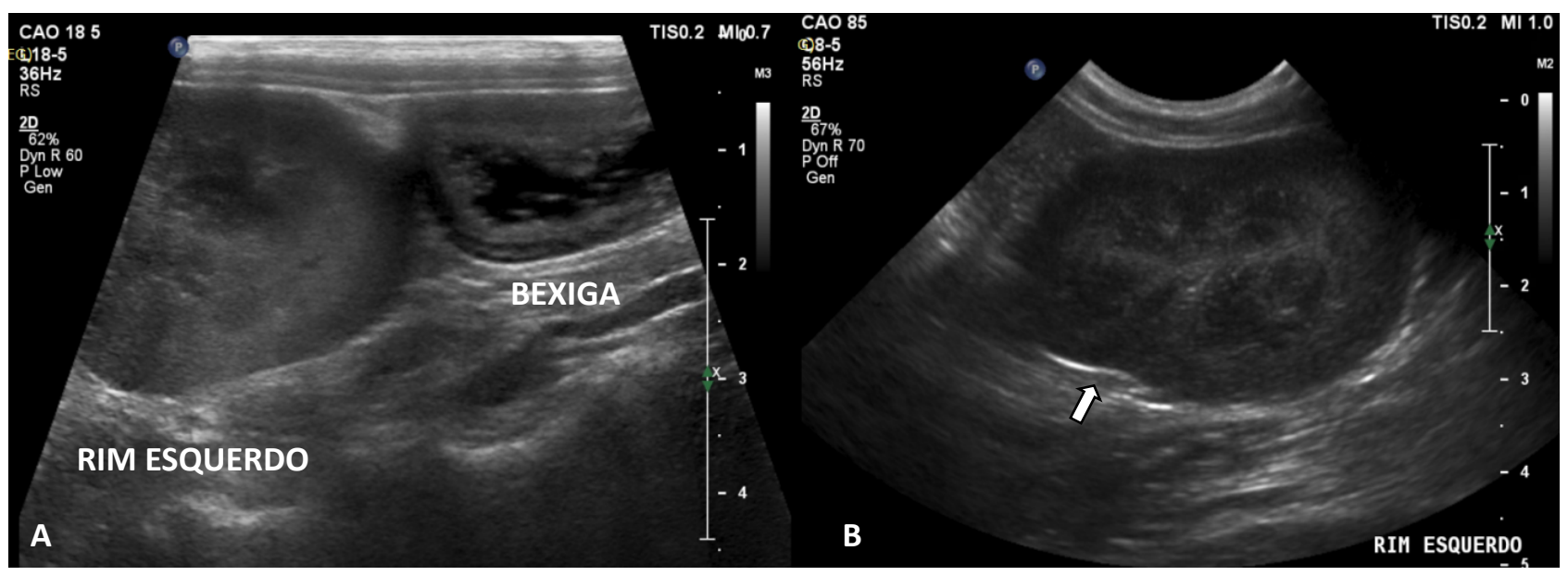

Source: The authors.

Figure 1. Ultrasound images of the left kidney of a male Lhasa apso dog, ectopic, cranial to the bladder, with a thick and irregular wall, suggesting cystitis $(A)$, and slight flattening at the medial margin of the cranial pole (arrow) (B). 
Until the moment of these tests, the renal ectopy has not caused any damage to the renal function of the patient, or even other complications such as lithiasis or ureteral obstructions. However, the hypothesis of association of the recurrent cystitis to this congenital alteration cannot be discarded.

\section{DISCUSSION}

According to Moore et al. (2016), during the embryonic period the permanent kidneys are located in the pelvis, ventrally to the sacrum and close together. As the body of the embryo grows, the kidneys move away and gradually elevate in the abdomen, reaching their adult anatomical position at the beginning of the fetal stage. The location of the left kidney of the patient in the caudal abdomen, combined with the reduced ureteral length, suggests that the ascension of this organ was not complete, bringing up the possibility of a defect in the development of the ureteric bud or metanephric mesenchyme as an etiologic factor. As Allworth and Hoffman (1999) suggested, a lesion in the renal tissue may be responsible for the failure of normal kidney ascension.

In this case, the left kidney was out of its usual topography in a male patient, corroborating what Allworth and Hoffman (1999) claimed, that the left kidney is affected more often and with higher incidence in males. In humans, the disease is also observed more frequently in males.

Bruckner et al. (2010) reported that the condition in question is an incidental finding. This is because renal ectopy is usually limited to a structural abnormality that does not

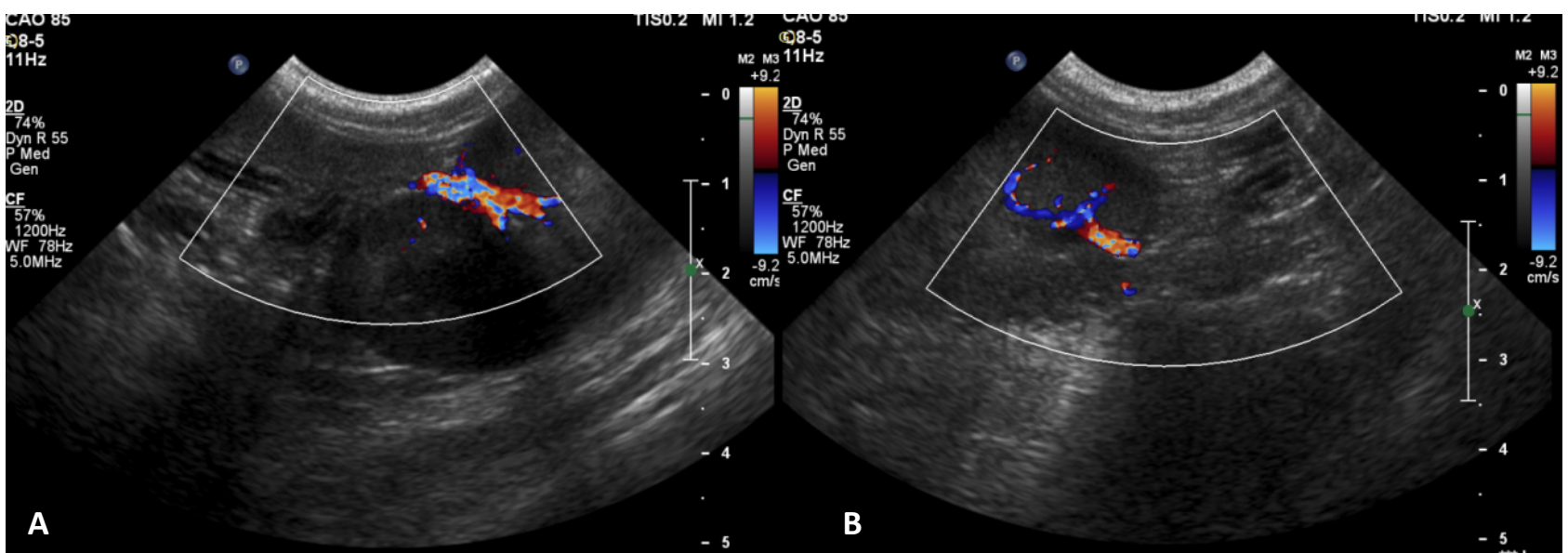

Source: The authors.

Figure 2. Ultrasound images of the left kidney of a male, Lhasa apso dog, ectopic at the color Duplex Doppler mode, showing the cranioventrally projected renal hilum (A), and a pulsating vessel emerging from the interlobar arteries (B)

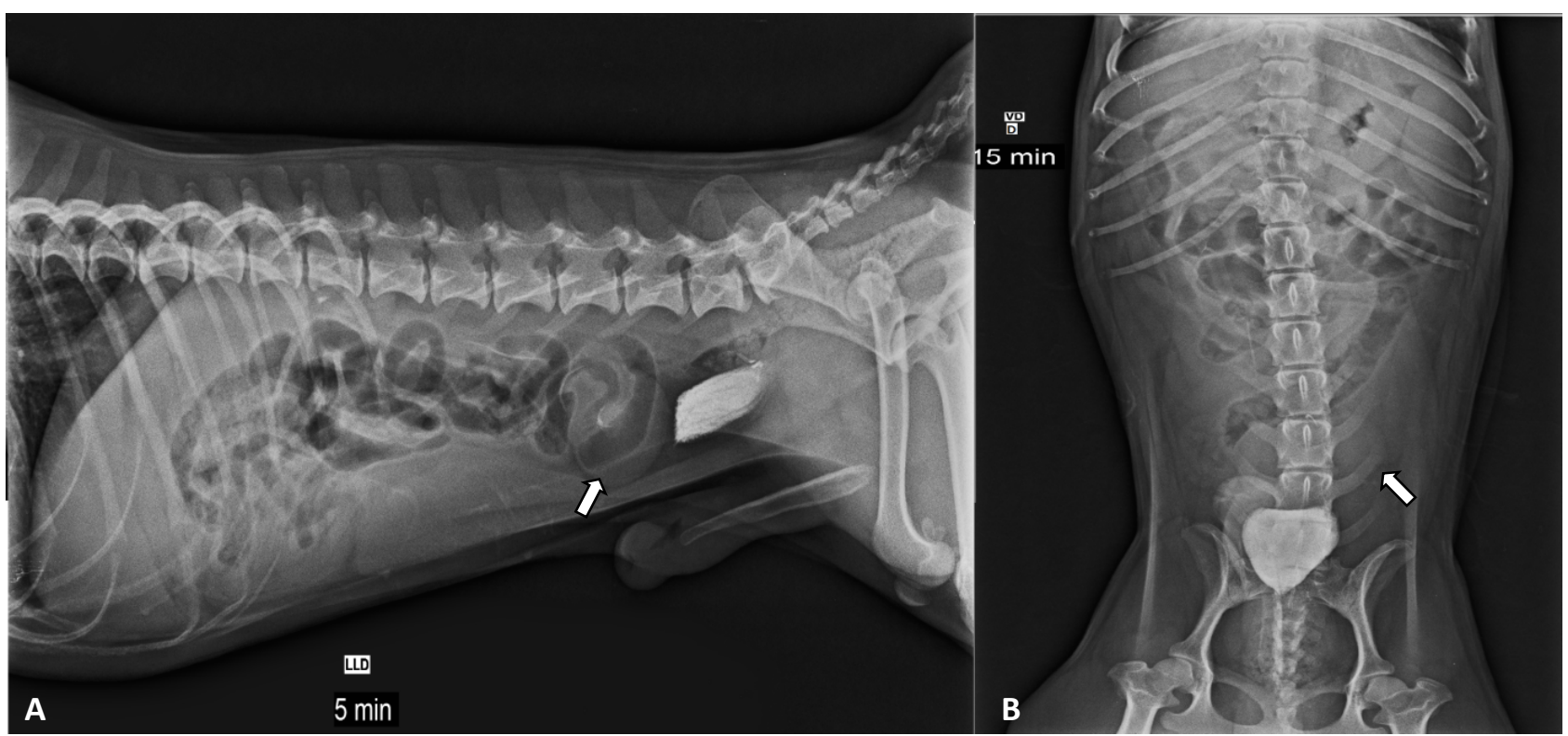

Source: The authors.

Figure 3. Radiographic images of a dog, male, Lhasa apso, in right lateral (A) and ventrodorsal (B) views of the abdominal cavity during the excretory urography. The left kidney is highlighted by the contrast medium with the pelvis delineated and the shape preserved, localized ventrally to the vertebrae L5 and L6 (white arrow), with the proximal ureter also filled by the contrast medium, projected cranially and reduced length (black arrow). 
compromise the renal function and is eventually diagnosed when the patient undergoes some imaging examination. In this case, the main complaint reported was cystitis and the presence of a palpable structure in the caudal abdomen with suspected neoformation, when the ectopic left kidney was being treated. Laboratory changes compatible with renal injury were not observed.

Ultrasound, radiography, and excretory urography are diagnostic modalities that can be employed in cases of renal ectopy (JOHNSON, 1979; NYLAND and MATTOON, 2005; BRUCKER et al., 2010). In Medicine, computed tomography and magnetic resonance imaging have replaced excretory urography in the evaluation of the urogenital system (CAOILI et al., 2002). The difficulty in accessing computed tomography and the high cost of the exam were obstacles for the tutor, since the patient was clinically stable. Thus, the diagnosis was established without prejudice with ultrasound and excretory urography.

Generally, renal ectopy may be accompanied by the anomalous vascularization in the affected kidney (JOHNSON, 1979). The anomalous vessel observed emerging from the renal interlobar arteries has a pulsating characteristic, flowing into a large caliber vessel in the region. This vessel might be associated to the remaining artery originating from the aorta, responsible for the blood supply of the primitive fetal kidney, which should involute with the kidney migration. In the presence of these vascular alterations, TC angiotomography would be the ideal exam to detect and map the changes in the vascular bed of the urogenital system, as Mello Junior et al. (2016) stated.

According to Fotter (2008), malrotation of the kidneys was regularly associated with an ectopic or fused kidney, increasing the possibility of obstruction of the pelvis and ureters. Also according to the author, incomplete rotation, and nonrotation of the kidneys were the most common condition when compared to the other subtypes of kidney rotational anomalies. In the present case, it was possible to observe a cranial projection of the left renal pelvis, suggesting malrotation. In order to classify the type of rotation that is involved, a type of exam that reproduces images in several planes, such as computerized tomography, is recommended.
In the embryonic period the kidneys are subdivided into lobules that disappear with renal maturation as the nephrons enlarge and grow (MOORE et al., 2016). Fetal lobulation can persist in humans into adulthood, being diagnosed incidentally from imaging examinations and mistakenly considered a disease (WILLIAMS, 2007). The flattening observed in the medial margin of the cranial pole may be related to the persistence of fetal lobulation. However, the absence of TC imaging of this kidney prevents further information. Therefore, we have considered it only a change in the shape of the affected kidney.

In humans, the kidney displacement can also occur traumatically, such as in the violent acceleration or braking, resulting in the avulsion of the collecting system or injury to the vascular pedicle (SILVA et al., 2009). Diaphragmatic hernias are also among the causes of acquired intrathoracic ectopic kidney (CAVALLI et al., 2011). The reports of renal ectopy in animals in the literature involve congenital malformation. The absence of a history of abdominal trauma added to the altered shape, vascular, and rotational anomalies, with reduced ureteral length, bring about the possibility that the renal ectopy in question has a congenital origin. According to its location, it was classified as abdominal, with the kidney being located cranially to the ilium and caudally to the diaphragm, as stated by Lulich et al. (1987) and Kim (2012).

Neoplastic processes count as differential diagnoses for renal ectopy in human and veterinary medicine (LULICH et al., 1987), corroborating the main suspicion of the clinician in charge at the Veterinary Hospital. This is due to the fact that the kidney is a massive structure, and once out of its usual topography might be mistaken for an abdominal mass when palpable.

\section{CONCLUSIONS}

As described in this clinical case, usually asymptomatic, renal ectopy is a congenital condition that is rarely diagnosed in small animals. Imaging exams such as ultrasound and excretory urography can conclude the diagnosis. Although ectopic kidneys are clinically silent, they are more prone to disease than normal kidneys. Therefore, monitoring the patient for urinary tract disorders is recommended.

\section{REFERENCES}

ALLWORTH, M. S.; HOFFMANN, K. L. Crossed renal ectopia with fusion in a cat. Veterinary Radiology \& Ultrasound, v. 40, п. 4, p. 357-360, 1999.

BARBARIC, Z. L. Principles of genitourinary radiology. 2. ed. New York, NY: THIEME, 1994. 500 p.

BRÜCKNER, M. et al. Simple renal ectopia in a cat. Tierärztliche Praxis. Ausgabe K, Kleintiere/Heimtiere, v. 38, n. 3, p. 163$166,2010$.
CAOILI, E. M.; COHAN, R. H.; KOROBKIN, M. et al. Urinary tract abnormalities: initial experience with multidetector row CT urography. Radiology, v. 222, n. 2, p. 353-360, 2002.

CAVALLI, R. C. et al. Ectopia renal intratorácica: relato de caso e revisão de literatura. Revista médica do Paraná, p. 14-16, 2011.

CHARAN, K.;PAWAIYA, R.V.S. Anunusual congenital anomaly: Ectopic sigmoid kidney combined with hermaphroditism in a newly born calf. Anatomia, histologia, embryologia, v. 26, n. 4, p. 269-270, 1997. 
$\mathrm{CHOI}, J$. et al. Simple ectopic kidney in three dogs. Journal of Veterinary Medical Science, v. 74, n.10, p. 1373-13-75, 2012.

FOTTER, R. Pediatric uroradiology. 2. ed. Berlin: Springer-Verlag, 2008. 552 p.

GRECO, D. S. Congenital and inherited renal disease of small animals. Veterinary Clinics: Small Animal Practice, v. 3l, n. 2, p. 393-399, 2001.

JOHNSON, C. A. Renal ectopia in a cat: a case report and literature review. Journal of the American Animal Hospital Association, v. 15, p. 599-602, 1979.

KIM, S. H. Radiology illustrated - uroradiology. 2. ed. Berlin: Springer-Verlag; 2012. 1292 p.

KUMAR,V:;ABBAS,A.K;FAUSTO,N.RobbinseCotran-Patologia:bases patológicasdasdoenças.7.ed. Rio de Janeiro, RJ:Elsevier;2005.1504p.

LEES, G. E. Congenital renal diseases. Veterinary Clinics of North America: small animal practice, v. 26, n. 6, p. 1379-1399, 1996.

LULICH, J. P.; OSBORNE, C. A.; LAWLER, D. F. et al. Urologic disorders of immature cats. Veterinary Clinics of North America: Small Animal Practice, v.17, n. 3,p. 663-696, 1987.
MELLO JÚNIOR, C. F. et al. Angiotomografia computadorizada por multidetectores das artérias renais: anatomia normal e suas variações. Radiologia Brasileira, v. 49, n. 3, p. 190-195, 2016.

MOORE, K. L.; PERSUAD, T. V. N.; TORCHIA, M. G. Embriologia clínica. 10. ed. Rio de Janeiro: Elsevier, 2016. 552 p.

NEWMAN, S. J. et al. Sistema Urinário. In:McGAVIN, M. D.;ZACHARY, J. F. Bases da patologia em veterinária. Rio de Janeiro: Elsevier, 2013, 5. ed., cap. 11,p.1544-1726.

NYLAND, T.G.;MATTOON, J.S. Ultrassom diagnóstico em pequenos animais. 2. ed. São Paulo: Roca, 2005. p. 161-198.

SILVA, L. F.; TEIXEIRA, L. C.; REZENDE NETO, J. P. Abordagem do trauma renal-artigo de revisão: review oftheliterature. Revista do Colégio Brasileiro de Cirurgiões, v. 36, n. 6, p. 519-524, 2009.

SOLANKI, S. et al. Crossed fused renal ectopia: challenges in diagnosis and management. Journal of Indian Association of Pediatric Surgeons, v. 18, n. 1, p. 7, 2013.

TRAPP, S. M. et al. Causas de óbito e razões para eutanásia em população hospitalar de cães e gatos. Brazilian Journal of Veterinary Research and Animal Science, v.47, n.5, p.395402,2010 